Relations industrielles

Industrial Relations

\title{
Bamber, Greg and Russell D. Lansbury (editors), International and Comparative Employment Relations
}

\section{Anthony Giles}

Volume 54, numéro 3, 1999

URI : https://id.erudit.org/iderudit/051259ar

DOI : https://doi.org/10.7202/051259ar

Aller au sommaire du numéro

Éditeur(s)

Département des relations industrielles de l'Université Laval

ISSN

0034-379X (imprimé)

1703-8138 (numérique)

Découvrir la revue

Citer ce compte rendu

Giles, A. (1999). Compte rendu de [Bamber, Greg and Russell D. Lansbury (editors), International and Comparative Employment Relations]. Relations industrielles / Industrial Relations, 54(3), 618-619.

https://doi.org/10.7202/051259ar

Tous droits réservés @ C Département des relations industrielles de l'Université Laval, 1999
Ce document est protégé par la loi sur le droit d'auteur. L'utilisation des services d'Érudit (y compris la reproduction) est assujettie à sa politique d'utilisation que vous pouvez consulter en ligne.

https://apropos.erudit.org/fr/usagers/politique-dutilisation/ 
debate over flexibility in labour markets and some of the key competing theories relevant to this debate. In addition, the Canada-Sweden comparative analysis itself highlights the importance of understanding the role of alternative forms of institutional arrangements in the functioning of the labour market.

\section{RICHARD CHAYKOWSKI}

Queen's University

\section{International and Comparative Employment Relations}

edited by Greg J. BAMBER and Russell D. LANSBURY, $3^{\text {rd }}$ edition, London: Sage Publications, 1998, 442 p., ISBN 0-7619-5592-5 (hbk) and 0-7619-5591-7 (pbk).

When I reviewed the first edition of this book in Relations industrielles/Industrial Relations way back in 1988 , I gave it rather short shrift since, in the space of a single review, I was also commenting on Maurice, Sellier and Silvestre's The Social Foundations of Industrial Power. For obvious reasons, the latter was a much more provocative read, and I therefore passed over the Bamber and Lansbury volume rather hastily. So, I now have an opportunity to redeem myself by taking a fresh look at this new edition of what has become a venerable textbook in the field of industrial relations... or rather, as the editors now prefer to say, "employment relations."

International and Comparative Employment Relations opens with a brief word of welcome from Tom Kochan, followed by a preface in which the editors explain the purpose of the book and its internal structure. Chapter 1 then provides a general introduction to "comparative and international" employment relations, including a definition of the field, an enumeration of the reasons for engaging in comparative and international research, and a discussion of some of the methodological issues facing comparativists.

The next eleven chapters are individual country studies on Great Britain (by John Goodman, Mick Marchington, John Berridge, Ed Snape and Greg Bamber), the United States (by Hoyt Wheeler and John McClendon), Canada (by Mark Thompson), Australia (by Edward Davis and Russell Lansbury), Italy (by Claudio Pellegrini), France (by
Janine Goetschy and Annette Jobert), Germany (by Friedrich Fürstenberg), Sweden (by Olle Hammarström and Tommy Nilsson), Japan (by Yasuo Kuwahara), and Korea (by Park Young-bum and Chris Leggett).

The final chapter, authored by the editors and Oliver Clarke, seeks to draw some general conclusions. The book is rounded out by an appendix that, at first glance, appears to be a mere compilation of statistics (twenty-five tables of them to be precise), but actually turns out to offer a wealth of information about the strengths and weaknesses of international statistics, as well as useful commentaries on how these statistics are used (and occasionally misused) in the industrial relations literature.

A side-by-side collection of this sort serves two basic purposes - as a teaching tool and as a sourcebook of concise country studies for the harried scholar. On both of these counts, this $3^{\text {rd }}$ edition scores high points. The individual chapters are generally well written (or competently translated) and are reasonably up to date. Moreover, the editors have clearly made an effort to ensure that the authors follow a roughly common structure, which greatly aids in comparison. My own students find the volume useful as an introduction to the broad array of national systems in the industrialized countries, though they also find it necessary to supplement it when, for example, they wish to explore a particular country's experience in more depth or when they begin to think about explicitly 
comparative issues. Bamber and Lansbury's overview chapter is a helpful introduction to such questions, but hardly a replacement for the more thematic comparative analyses offered by, say, Ron Bean's Comparative Industrial Relations (Routledge, 1994) or Hyman and Ferner's New Frontiers in Industrial Relations (Blackwell, 1994). From a pedagogical point of view, the ideal is to assign a compendium of national studies like this one, along with a more explicitly comparative treatment of the subject.

As for the second purpose, the volume will also prove useful to the scholar seeking a quick overview of one of the included countries. In addition, each of the chapters has a useful chronology of key events; and there are separate bibliographies for each country to guide more extensive research.

Having attained redemption of sorts, let me turn to several key questions raised by International and Comparative Employment Relations which deserve comment.

First, although the shift from "industrial relations" to "employment relations" is unquestionably laudatory, not all of the individual chapters have made the transition smoothly or completely. For example, Mark Thompson's otherwise concise and balanced overview of the Canadian system is essentially a summary of the Canadian $I R$ system as traditionally conceived. Other chapters also reflect this more traditional definition, not least because, after a brief introduction to the historical, political and socio-economic context, each then turns immediately to an analysis of the "employment relations parties." This curiously traditional way of framing the subject inevitably introduces an institutionalist bias in the subsequent treatment of work and employment. Thus, if the intention is to broaden the practical definition of the field, more needs to be done than simply changing the name.
A second goal of the book is to promote an "internationally comparative" approach to the subject. Here again the editors are to be congratulated for reminding us of the intimate connections between the "comparative" and "international" sub-fields of industrial/employment relations. Disappointingly, however, this ambition is not entirely realized. Indeed, despite the promise of a "synthesis of international and comparative experience in employment relations" in the title of the concluding chapter, the ensuing discussion remains a prisoner of the distinction between the two areas. Thus, the first half of the chapter examines comparative issues (i.e., crossnational similarities and differences), whereupon the second half takes up international issues (multinational firms and the like). That said, the editors are correct to emphasize the need to merge these two areas, even if their own treatment doesn't quite attain the objective.

Finally, although the addition of a chapter on Korea widens the coverage of the book beyond the traditional set of advanced capitalist nations, it also raises, for this reviewer, the larger issue of the exclusion of other country-types, notably, the developing nations and those of Central and Eastern Europe. Are our concepts too spatially constricted to apply to work and employment relations wherever they occur? We shouldn't pick on Bamber and Lansbury's volume in this respect, for by including Korea they go one step further than the typical collection. Still, in the context of increasingly globalized production, the inclusion of a wider range of "cases" would serve not only to demonstrate to students the existence of other systems for managing work, but would also lay the basis for an examination of the growing linkages across nations - or, in other words, move us toward the synthesis that the editors so rightly call for.

ANTHONY GILES Université Laval 